\title{
Linking Redox Regulation of NMDAR Synaptic Function to Cognitive Decline during Aging
}

\author{
Ashok Kumar and Thomas C. Foster \\ Department of Neuroscience, McKnight Brain Institute, University of Florida, Gainesville, Florida 32610
}

\begin{abstract}
NMDA receptors (NMDARs) play a critical role in learning and memory; however, there is a lack of evidence for a direct relationship between a well characterized decline in NMDAR function and impaired cognition during aging. The present study was designed to test the idea that a redox-mediated decrease in the NMDAR component of synaptic transmission during aging is related to a specific cognitive phenotype: impaired memory for rapidly acquired novel spatial information. Young and middle-aged male F344 rats were provided $1 \mathrm{~d}$ of training on the spatial version of the water maze, and retention was examined $24 \mathrm{~h}$ later. The performance of young rats was used as a criterion for classifying middle-aged rats as impaired and unimpaired on the task. Subsequent construction of CA3-CA1 synaptic input- output curves in hippocampal slices confirmed an age-related decrease in synaptic responses, including the NMDAR component of synaptic transmission. Examination of synaptic transmission according to behavioral classification revealed that animals classified as impaired exhibited a decrease in the total and the NMDAR component of the synaptic response relative to unimpaired animals. Furthermore, bath application of the reducing agent dithiothreitol increased the NMDAR component of the synaptic response to a greater extent in impaired animals relative to unimpaired and young rats. These results provide evidence for a link between the redox-mediated decline in NMDAR function and emergence of an age-related cognitive phenotype, impairment in the rapid acquisition and retention of novel spatial information.
\end{abstract}

\section{Introduction}

The NMDA receptor (NMDAR) component of synaptic transmission declines during aging (Barnes et al., 1997; Billard and Rouaud, 2007; Bodhinathan et al., 2010a). NMDARs are intimately involved in memory; however, there is a lack of evidence for a direct link between decreased NMDAR function and agerelated memory impairment (Foster, 2012). Research indicates that NMDARs are involved in memory for rapidly acquired and flexible spatial information (e.g., working memory), rather than the incremental acquisition of a reference memory (Nakazawa et al., 2003; Bannerman et al., 2008; von Engelhardt et al., 2008), and NMDAR antagonists disrupt retention of novel spatial information as retention intervals increase (Steele and Morris, 1999; McDonald et al., 2005). Interestingly, the acquisition and retention of novel or flexible spatial information is highly sensitive to aging, developing in middle age, before spatial reference memory deficits (Jucker et al., 1988; Ando and Ohashi, 1991; Foster, 2012). The results suggest that a deficit in the rapid acquisition and consolidation of spatial information is an early phenotype of cognitive aging, possibly due to a decline NMDAR function.

\footnotetext{
Received May 22, 2013; revised Aug. 23, 2013; accepted Aug. 28, 2013.

Author contributions: A.K. and T.C.F. designed research; A.K. performed research; A.K. and T.C.F. analyzed data; A.K. and T.C.F. wrote the paper.

This research was supported by National Institute on Aging Grants AG037984 and AG036800, and by the McKnight Brain Research Foundation. We thank Asha Rani, Michael Guidi, Kristina Velez, and Paul Huang for technical assistance.

Correspondence should be addressed to Dr. Thomas C. Foster, Department of Neuroscience, McKnight Brain Institute, University of Florida, PO Box 100244, Gainesville, FL 32610-0244. E-mail: foster1@ufl.edu.

DOI:10.1523/JNEUROSCI.2176-13.2013

Copyright $\odot 2013$ the authors $\quad 0270-6474 / 13 / 3315710-06 \$ 15.00 / 0$
}

Recent work demonstrates that an age-related decrease in NMDAR function is related to oxidative stress and a postsynaptic shift in the intracellular oxidation-reduction (redox) environment (Bodhinathan et al., 2010a; Robillard et al., 2011; Haxaire et al., 2012). Increased oxidative stress and diminished NMDARdependent synaptic plasticity develop in middle age (Zhang et al., 1993; Rex et al., 2005; Ghosh et al., 2012), suggesting that NMDAR function may decline in middle age. The current study focuses on middle age to examine the idea that cognitive deficits that arise at this time are related to a redox-mediated decline in NMDAR synaptic responses.

\section{Materials and Methods}

Animals. Procedures involving animals have been reviewed and approved by the Institutional Animal Care and Use Committee of the University of Florida, and are in accordance with guidelines established by the US Public Health Service Policy on Humane Care and Use of Laboratory Animals. Young (5-8 months, $n=11)$ and middle-aged (12-16 months, $n=34$ ) male Fischer 344 rats were obtained from National Institute on Aging colony at Harlan.

Behavioral characterization. Methods for behavioral assessment of cognition using the water maze have been published previously (Kumar et al., 2012; Foster et al., 2012; Speisman et al., 2013). Rats were first trained on the cue discrimination version of the water escape task using five blocks of three trials with all training massed into $1 \mathrm{~d}$. Three days later, animals were trained on the spatial discrimination version of the task. Procedures for spatial learning were similar to the cue training, consisting of six blocks of three trials with all training massed into a single day. Probe trials delivered between blocks five and six and $24 \mathrm{~h}$ later were used to evaluate the use of a spatial search strategy.

Hippocampal slice preparation and electrophysiological recordings. Methods for hippocampal slice preparation and electrophysiological re- 

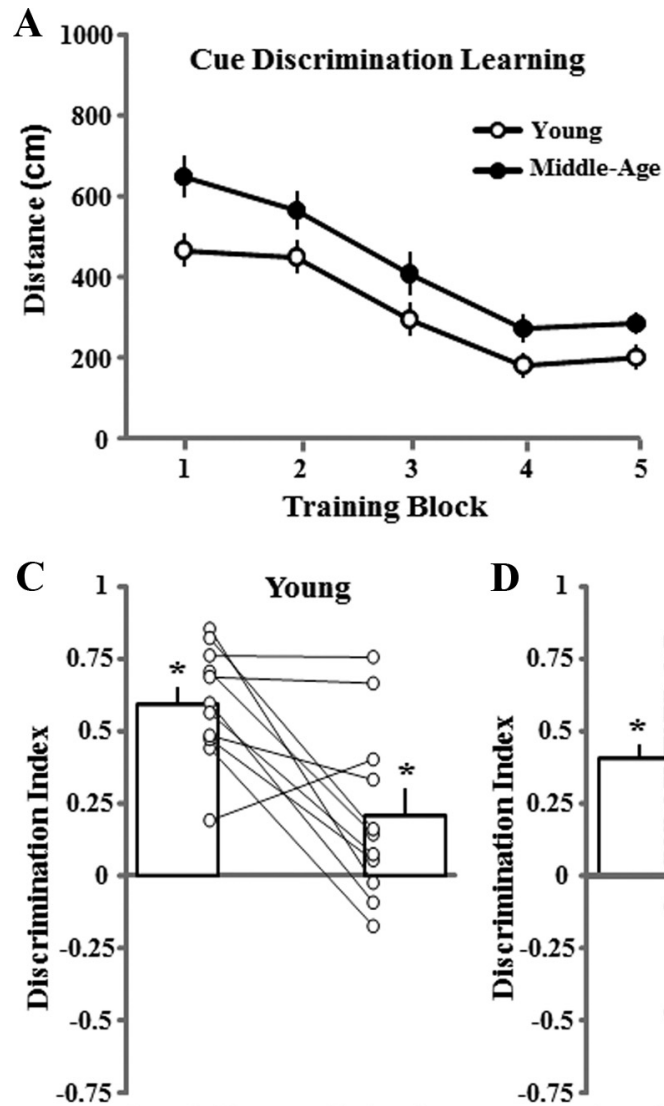

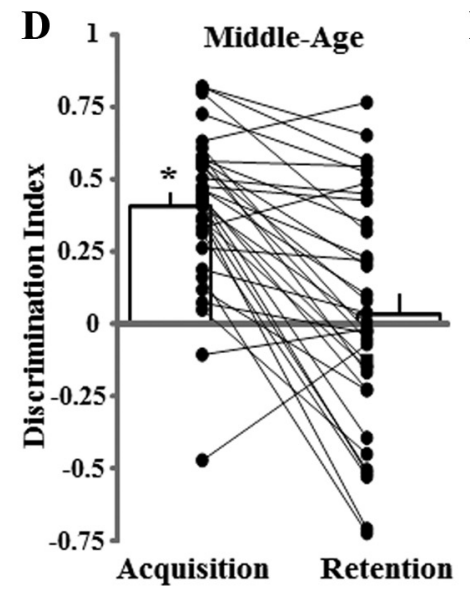

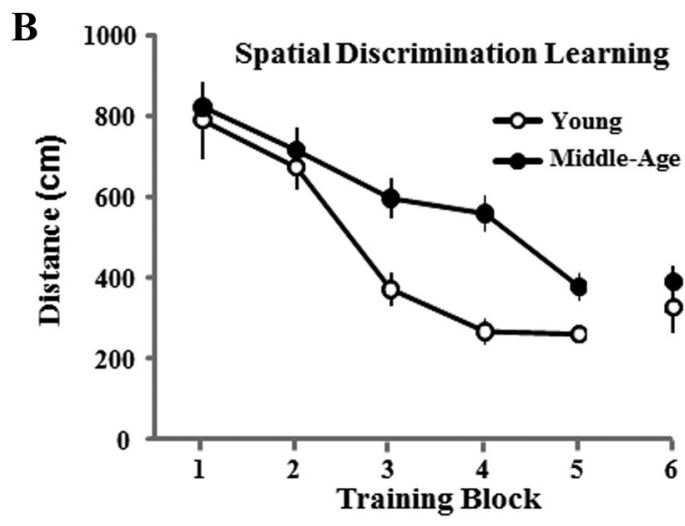

$\mathbf{E}$

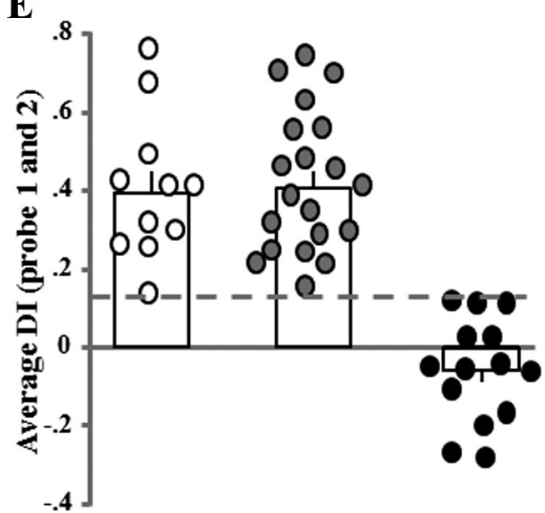

Young Unimpaired Impaired

Figure 1. Characterization of learning and memory on the water maze. $A, B$, Mean distance traveled ( \pm SEM) per training block during performance of the cue $(A)$ and spatial discrimination tasks (B) for young (open circles, $n=11$ ) and middle-aged (filled circles, $n=34$ ) rats. $\boldsymbol{C}, \boldsymbol{D}$, Bars represent the mean \pm SEM discrimination index (DI) scores for the acquisition and retention probe trials for young $(\boldsymbol{C})$ and middle-aged $(\boldsymbol{D})$ rats. The line graphs show individual $D I$ scores. The DI scores were computed for the $60 \mathrm{~s}$ probe trials according to the formula $(G-0) /(G+0)$, where $G$ and 0 represent the percentages of time spent in the goal and in opposite quadrants, respectively. The asterisk indicates that the mean discrimination index is $>0$ (i.e., chance performance). $\boldsymbol{E}$, The DI scores were averaged across the two probe trials for each animal. A cutoff criterion (dashed line) was set at the lowest value for young animals (open circles). Animals with scores below this criterion were classified as impaired (filled circles, $n=14$ ), and those above this value were classified as unimpaired (gray circles, $n=20$ ). The open bars represent the mean of the averaged DI scores for each group.

cording of total and NMDAR-mediated synaptic responses have been published previously (Bodhinathan et al., 2010a). Briefly, 1-2 weeks following behavioral characterization, hippocampi were harvested and slices $(\sim 400 \mu \mathrm{m})$ were cut parallel to the alvear fibers. Slices were placed in a recording chamber and were bathed in $30 \pm 0.5^{\circ} \mathrm{C}$ oxygenated artificial CSF (ACSF) as follows (in mM): $\mathrm{NaCl} 124, \mathrm{KCl} 2, \mathrm{KH}_{2} \mathrm{PO}_{4} 1.25$, $\mathrm{MgSO}_{4} 2, \mathrm{CaCl}_{2} 2, \mathrm{NaHCO}_{3} 26$, and glucose 10 .

Extracellular field EPSPs (fEPSPs) from stratum radiatum of CA1 were recorded with glass micropipettes (4-6 M $\Omega$ ) filled with ACSF. A stimulating electrode was positioned $\sim 1 \mathrm{~mm}$ away in the middle of the stratum radiatum. Field potentials $(0.033 \mathrm{~Hz})$ were evoked by diphasic stimulus pulses $(100 \mu \mathrm{s})$. Signals were amplified, filtered $(1 \mathrm{~Hz}$ and $1 \mathrm{kHz})$, and stored on computer for off-line analysis.

To obtain the NMDAR-mediated component of synaptic transmission (NMDAR-fEPSP), slices were incubated in ACSF containing low $\mathrm{Mg}^{2+}(0.5 \mathrm{~mm}), 6,7$-dinitroquinoxaline-2,3-dione (DNQX; $30 \mu \mathrm{M}$ ) and picrotoxin (PTX; $10 \mu \mathrm{M}$ ). Input-output curves for the total and NMDAR-fEPSP slope (in millivolts per milliseconds) were constructed for increasing stimulation intensities. To examine dithiothreitol (DTT) effects, the baseline response was set at $\sim 50 \%$ of maximum, and responses were collected for at least $10 \mathrm{~min}$ before and $60 \mathrm{~min}$ after drug application. The DTT dose $(0.5 \mathrm{~mm})$ was selected due to previous studies that show this dose is within a range that can increase NMDAR responses specifically in aged animals, and in young animals under oxidizing conditions, and yet is below a dose that impairs enzyme activity (Tang and Aizenman, 1993; Bodhinathan et al., 2010a).
DNQX (Sigma) was initially dissolved in dimethylsulfoxide (DMSO; Sigma) and diluted in ACSF to a final DMSO concentration of $<0.01 \%$ and to a final DNQX concentration of $30 \mu \mathrm{M}$. PTX (Tocris Bioscience) was initially dissolved in ethanol and diluted in ACSF to a final ethanol concentration of $0.0001 \%$ and to a final PTX concentration of $10 \mu \mathrm{M}$. DTT was directly dissolved in ACSF.

Statistical analysis. ANOVAs were used to establish main effects. Follow-up ANOVAs or Fisher's PLSD post hoc tests $(p<0.05)$ were used to localize differences. In some cases, $t$ tests were used to determine whether search behavior was different from chance and whether DTT induced a change in the synaptic response. Where stated, $n$ represents the number of animals used in each experiment.

\section{Results}

Characterization of spatial learning and memory

An ANOVA on escape path length across the five blocks of cue discrimination training indicated a significant age effect $\left(F_{(1,172)}=8.8, p<0.005\right)$ due to a greater path length for middleaged $(n=34)$ compared with young $(n=11)$ animals (Fig. $1 A)$. Post hoc ANOVAs indicated a significant effect of training $(p<$ 0.0001 ) in each age group, and no age difference was observed for the final block, indicating that groups acquired the cue task to about the same extent.

An ANOVA examining age and training effects for escape path length across blocks during spatial training indicated a significant age effect $\left(F_{(1,215)}=8.9, p<0.005\right)$ due to shorter escape path 

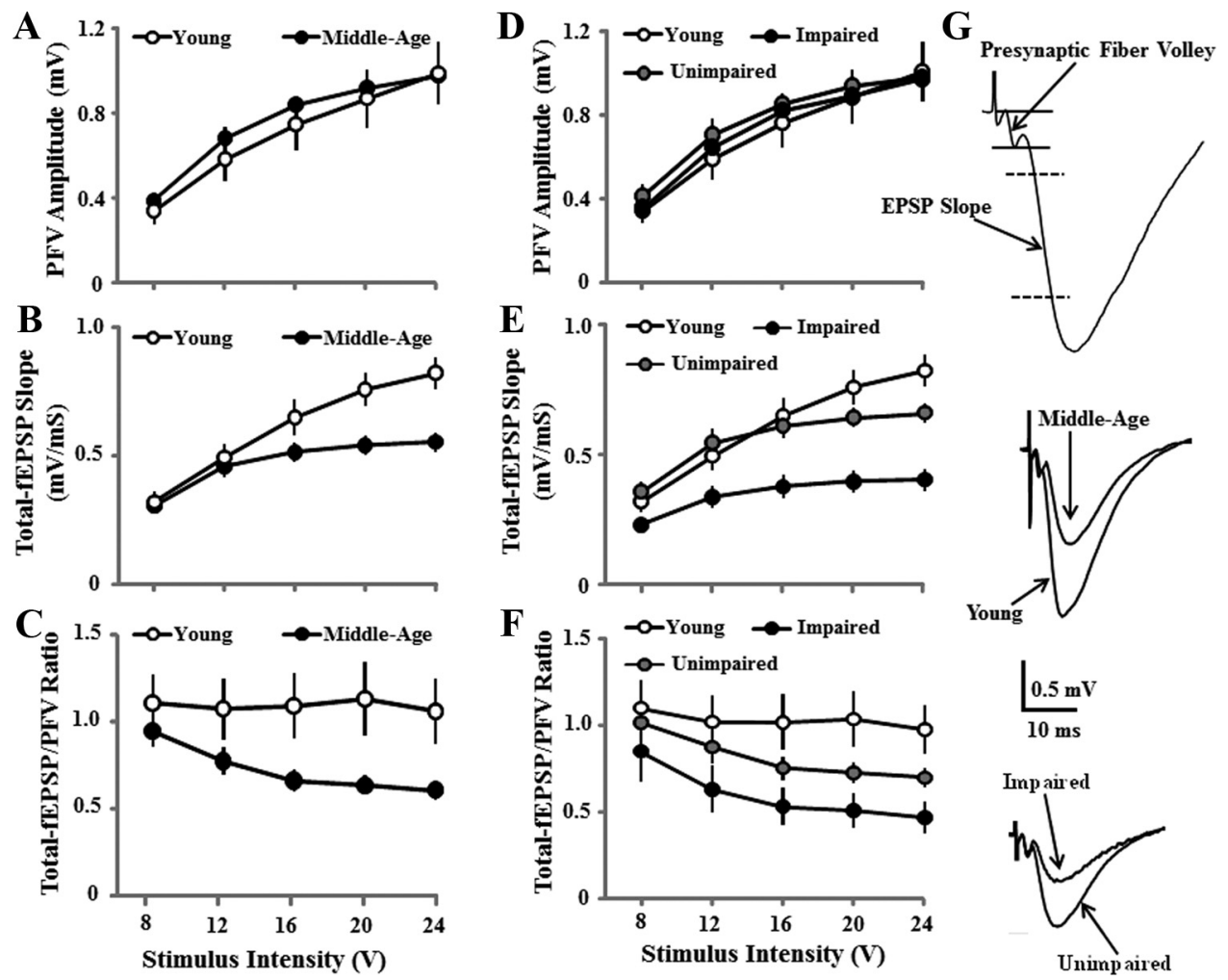

Figure 2. Decreased hippocampal synaptic strength during aging is related to cognitive function. $\boldsymbol{A}-\boldsymbol{C}$, Input- output curves for the mean \pm SEM amplitude of the PFV ( $\boldsymbol{A}$ ), slope of total-fEPSP $(\boldsymbol{B})$, and ratio of total-fEPSP/PFV ( $\boldsymbol{C}$ evoked by increasing stimulation voltage (V). Despite a similar PFV, a decrease in the synaptic response was observed in middle-aged (filled circles, $n=34$ ) relative to young (open circles, $n=11$ ) animals. $\boldsymbol{D}-\boldsymbol{F}$, Examination of synaptic transmission according to behavioral classification revealed that the decrease in the synaptic response was specific to animals classified as impaired (filled circles, $n=14$ ), and the slope of the total-fEPSP $(\boldsymbol{E})$ and ratio of total-fEPSP/PFV $(\boldsymbol{F})$ were not different between unimpaired (gray circles, $n=20$ ) and young (open circles, $n=11$ ) animals. $\mathbf{G}$, Representative field potential recordings in CA1 stratum radiatum showing (top) the regions for PFV and EPSP measures. The calibration bars are for the middle and bottom panels. The EPSP traces for the middle and bottom panels provide examples of responses for young and middle-aged animals (middle) and impaired and unimpaired animals (bottom), which exhibited similar PFVs and differences in the EPSP slope.

length of young relative to middle-aged animals (Fig. 1B). ANOVAs within each age group indicated a significant effect of training $(p<0.0001)$, and no age difference was observed for the final training block. An ANOVA on the discrimination index scores across the acquisition and retention probe trials indicated a tendency $(p=0.057)$ for an age difference and a significant difference across the $24 \mathrm{~h}$ period $\left(F_{(1,43)}=38.7, p<0.0001\right)$ due to a decrease in performance from acquisition to retention testing. One-group $t$ tests indicated that performance was above chance for both probe trials in young animals, and for the acquisition probe trial in middle-aged animals (Fig. 1C,D). The performance on the retention probe trial for middle-aged rats was not different from chance, which is consistent with increased forgetting of the novel spatial information (Foster, 2012). To classify middle-aged animals as impaired or unimpaired on the spatial task, the discrimination index scores were averaged across the two probe trials and a cutoff criterion was set at the lowest value for young animals (score $=0.134$; Fig. $1 E$ ). Middle-aged animals below this criterion were classified as impaired $(n=14,41 \%)$, and those above this value were classified as unimpaired $(n=20,59 \%)$. Reanalysis of performance during training on the cue and spatial discrimination tasks indicated no difference between impaired and unimpaired middle-aged animals (data not shown).

Basal synaptic transmission is reduced in impaired animals Input-output curves for presynaptic fiber volley (PFV) and total-fEPSP slope confirmed decreased synaptic transmission with advancing age. ANOVAs indicated the effects of stimulation in- tensity $\left(F_{(4,172)}=123.0, p<0.0001\right)$ in the absence of an age difference or an interaction for the PFV amplitude (Fig. 2A) and an age $X$ stimulation intensity interaction for the total-fEPSP slope $\left(F_{(4,172)}=15.5, p<0.0001\right)$ due to increased synaptic responses in young animals for higher stimulation intensities (Fig. $2 B$ ). The total-fEPSP/PFV ratio was calculated as an index of synaptic efficacy, and an ANOVA confirmed an age effect $\left(F_{(1,172)}=5.1, p<0.05\right)$ due to reduced efficacy in middleaged animals (Fig. $2 C$ ).

To determine whether decreased synaptic efficacy was associated with impaired cognitive function, the older animals were separated according to behavioral classification and analysis was conducted on all three groups (impaired, unimpaired, and young). The PFV increased with stimulation intensity $\left(F_{(4,168)}=\right.$ $160.8, p<0.0001$ ), but was not related to behavioral classification (Fig. 2D). An interaction of behavioral classification and stimulation intensity was observed for the total-fEPSP slope $\left(F_{(8,168)}=\right.$ $10.0, p<0.0001$ ), and post hoc tests indicated that the response was depressed for impaired animals relative to unimpaired and young animals (Fig. 2E). An ANOVA on the total-fEPSP/PFV ratio confirmed a group effect $\left(F_{(2,168)}=3.9, p<0.05\right)$ due to reduced synaptic efficacy for impaired animals relative to young animals (Fig. 2F).

The PFV for the NMDAR-fEPSP increased with increasing stimulation $\left(F_{(6,258)}=189.2, p<0.0001\right)$ and was not affected by age (Fig. $3 A$ ). In contrast, an age effect was observed for the NMDAR-fEPSP slope $\left(F_{(1,258)}=6.7 p<0.05\right.$; Fig. $\left.3 B\right)$ and the NMDAR-fEPSP/PFV ratio $\left(F_{(1,258)}=8.1, p<0.01\right.$; Fig. $\left.3 C\right)$ due 

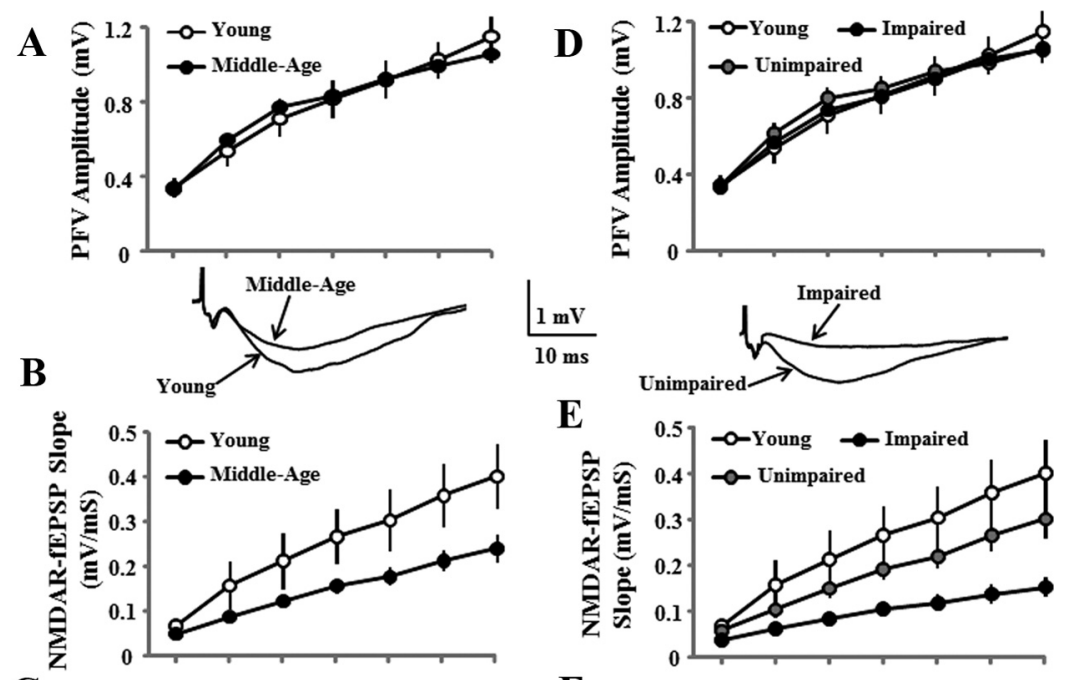

$\mathbf{E}$
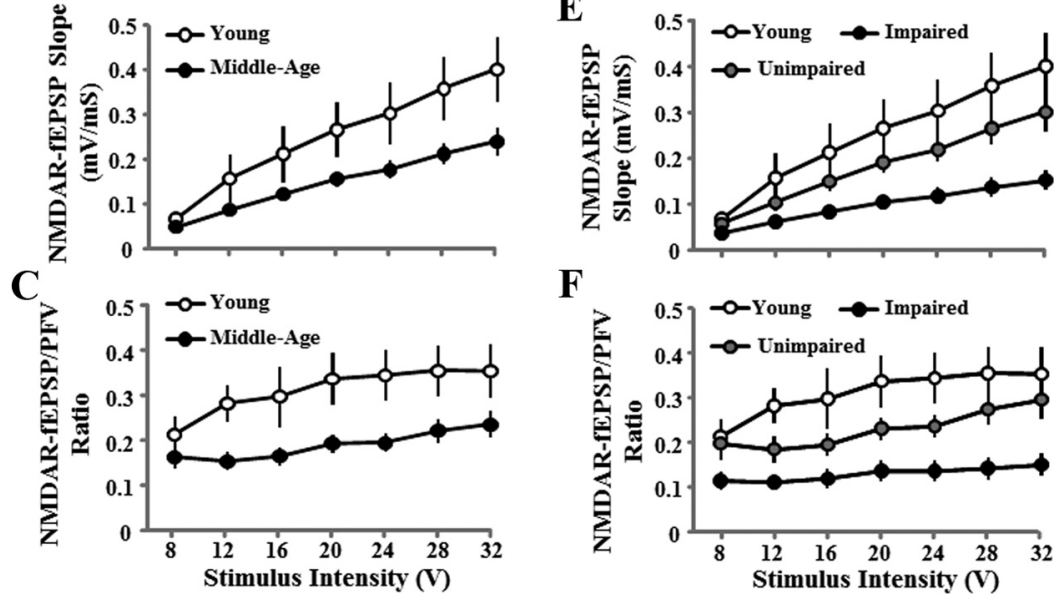

Figure 3. Reduced hippocampal NMDAR-fEPSP slope is related to cognitive function. $\boldsymbol{A}-\boldsymbol{C}$, Input- output curves for the mean SEM PFV amplitude $(\boldsymbol{A})$, NMDAR-fEPSP slope $(\boldsymbol{B})$, and ratio of NMDAR-fEPSP/PFV $(\boldsymbol{C})$ evoked by increasing the stimulation voltage (V). An age-related decrease in the synaptic response was observed in middle-aged (filled circles, $n=34$ ) relative to young (open circles, $n=11$ ) animals. $\boldsymbol{D}-\boldsymbol{F}$, The decrease in the slope of the NMDAR-fEPSP $(\boldsymbol{E})$ and ratio of the NMDAR-fEPSP/PFV $(\boldsymbol{F})$ was specific for cognitively impaired (filled circles, $n=14$ ) animals relative to unimpaired (gray circles, $n=20$ ) and young (open circles, $n=11$ ) animals. The inserts are representative NMDAR-fEPSP traces for young and middle-aged (left) and impaired and unimpaired (right) animals.

to greater responses in younger animals. When middle-aged animals were separated according to behavioral classification, the PFV for the NMDAR-fEPSP slope was not related to behavioral classification (Fig. 3D). An effect of group classification was observed for the NMDAR-fEPSP slope $\left(F_{(2,252)}=6.1, p<\right.$ $0.005)$ and the NMDAR_fEPSP slope for impaired animals was decreased relative to the unimpaired and young animals (Fig. $3 E)$. A main effect of group classification $\left(F_{(2,252)}=7.6, p<\right.$ 0.005 ) was observed for the NMDAR-fEPSP/PFV ratio and post hoc tests confirmed that synaptic efficacy for impaired animals was decreased relative to the unimpaired and young animals (Fig. 3F).

\section{Redox environment contributes to the decline in NMDAR function}

In a subset of young ( $n=3 / 5$ animals/slices), middle-aged unimpaired $(n=12 / 16)$, and middle-aged impaired $(n=7 / 8)$ animals, the NMDAR-fEPSP slope was set a $\sim 50 \%$ of maximum and recorded for $10 \mathrm{~min}$. Subsequent application of DTT resulted in a marked increase in the synaptic response for impaired animals (Fig. 4A). The percentage change in the PFV and NMDAR-fEPSP slope was averaged during the last $5 \mathrm{~min}$ of the $1 \mathrm{~h}$ recording, and averages were subjected to ANOVAs. An effect of behavioral classification was observed on the percentage change in the NMDAR-fEPSP slope $\left(F_{(2,19)}=7.3, p<0.005\right)$ due to a large increase in impaired animals relative to the other two groups (Fig. $4 A$ ). For impaired animals, an increase was observed in $100 \%$ of the slices ( 8 of 8 slices), and the raw NMDAR-fEPSP slope values were increased above baseline (paired $t$ test, $p>0.05$; Fig. $4 E$ ). The slope values were not increased for the other two groups, and an increase was observed in only $\sim 50 \%$ of the slices (young animals, 2 of 5 slices; unimpaired animals, 8 of 16 slices; Fig. $4 C, D$ ). Consistent with previous studies, no effect of DTT was observed on the PFV amplitude (Fig. $4 F$ ), pairedpulse facilitation (50 ms interpulse interval), or the total-fEPSP slope.

\section{Discussion}

Disruption of memory for rapidly acquired novel spatial information develops in middle age, before impaired acquisition of spatial reference memories, which is generally limited to the oldest animals (Jucker et al., 1988; Ando and Ohashi, 1991; Foster, 2012). In the current study, we demonstrate that the emergence of impaired retention of novel spatial information is associated with a redox-sensitive decrease in NMDAR synaptic transmission.

An age-related decrease in CA1 synaptic transmission is well characterized and is not associated with a change in measures of presynaptic function, PFV, or paired-pulse facilitation (Landfield et al., 1986; Barnes et al., 1992; Deupree et al., 1993; Norris et al., 1998; Hsu et al., 2002). Similarly, redox agents do not alter the PFV or paired-pulse facilitation. Rather, the effects of DTT are specific for the NMDAR component of synaptic transmission and are not observed for the AMPA receptor component (Aizenman et al., 1990; Gozlan et al., 1995; Bernard et al., 1997; Bodhinathan et al., 2010a). NMDAR function is increased by postsynaptic injection of the relatively membrane-impermeable redox buffer glutathione, suggesting a postsynaptic mechanism (Bodhinathan et al., 2010a). The current study demonstrates that the redox-related depression of NMDARs emerges in middle age, particularly in animals that exhibit impaired cognition. Redox regulation of NMDARs contributes to age-related impairment of long-term potentiation (LTP; Bodhinathan et al., 2010a; Robillard et al., 2011), which also emerges during middle age in association with impaired cognition (Rex et al., 2005; Fouquet et al., 2011). Finally, treatments to enhance NMDAR function improve the rapid acquisition of spatial information (Burgdorf et al., 2011; Brim et al., 2013), suggesting that decreased NMDAR function underlies impaired memory for rapidly acquired novel spatial information.

Impairment in spatial reference memory does not correlate with the decrease in NMDAR-mediated synaptic transmission (Tombaugh et al., 2002; Boric et al., 2008). This may not be surprising since the incremental acquisition of reference memory is observed for many pharmacological or genetic conditions that decrease hippocampal NMDAR function (Foster, 2012). Rather, disruption of hippocampal NMDARs impairs the consolidation of novel, rapidly acquired spatial information (Steele and Morris, 1999; McDonald et al., 2005; Bannerman et al., 2008; von Engelhardt et al., 2008). The results 

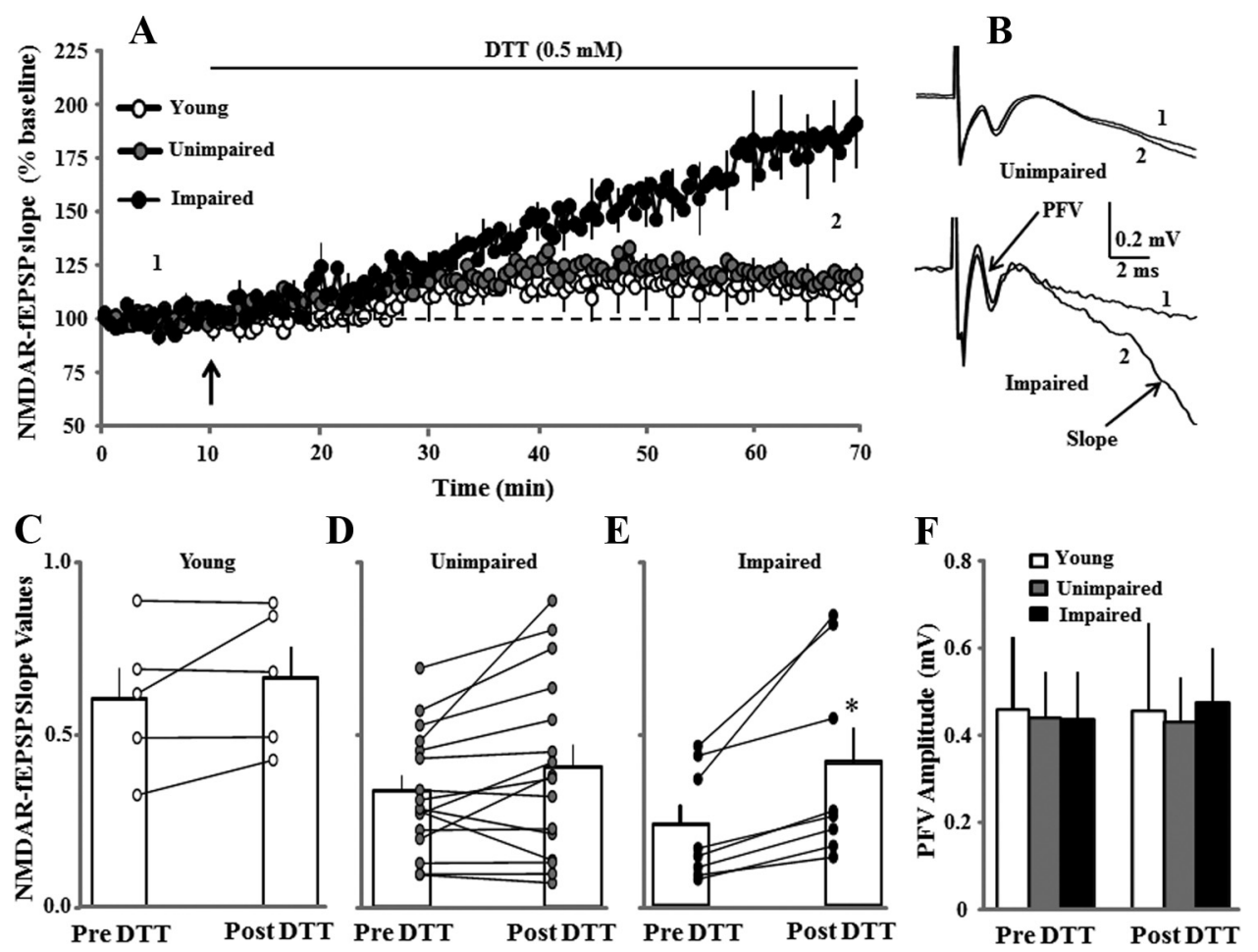

Figure 4. Redox environment contributes to the decline in NMDAR function associated with cognitive impairment. $A$, Time course of changes in the slope of NMDAR-fEPSP obtained from hippocampal slices $10 \mathrm{~min}$ before and $60 \mathrm{~min}$ after bath application of the reducing agent DTT ( $0.5 \mathrm{~mm}$, solid line) for young (open circles, $n=3 / 5$ animals/slices), unimpaired (gray circles, $n=12 / 16$ animals/slices), and impaired (filled circles, $n=7 / 8$ animals/slices) animals. $\boldsymbol{B}$, Representative traces illustrating the change in the NMDAR-fEPSP slope in the middle-aged unimpaired (top) and middle-aged impaired (bottom) animals under control conditions (1) and at the end of a $60 \mathrm{~min}$ (2) application of DTT. Note that DTT did not affect the PFV. C-E, Bars represent the mean \pm SEM NMDAR-fEPSP slope recorded for the pre- and post-DTT time points for young $(\boldsymbol{C}$ ), unimpaired $(\boldsymbol{D})$, and impaired $(\boldsymbol{E})$ animals. The line graphs show the change in the response for individual slices. $\boldsymbol{F}$, Bars represent the mean \pm SEM PFV amplitude before and after the application of DTT across the various groups. The asterisk indicates a significant increase in NMDAR-fEPSP slope from the pre-DTT condition.

indicate that the decrease in NMDAR function contributes to an early phenotype of cognitive decline: impaired spatial working memory.

Differences in the onset or progression of working and reference memory deficits may depend on independent mechanisms that age differentially (Foster, 2012). Alternatively, a decline in NMDAR function may precipitate more severe learning deficits with advancing age. In vitro studies indicate that synaptic NMDAR activity is important for transcription related to neuroprotection and antioxidant defenses (Hardingham et al., 2002; Papadia et al., 2008; Zhang et al., 2011). Thus, a decline in synaptic NMDAR signaling could render cells more vulnerable to aging stressors, including oxidative stress. Similarly, a redox shift may contribute to several aspects of hippocampal senescence, including increases in the $\mathrm{Ca}^{2+}$-dependent afterhyperpolarization (AHP), oxidative damage, neuronal vulnerability, and impaired cognition (Bodhinathan et al., 2010a; Ghosh et al., 2012; Lee et al., 2012). For example, growth of the AHP is associated with impaired learning (Tombaugh et al., 2005; Matthews et al., 2009), decreased NMDAR synaptic responses (Kumar and Foster, 2004), and impaired LTP (Foster and Norris, 1997; Foster, 2012). In turn, the redox state of ryanodine receptors mediates the agerelated growth in the AHP through the release of $\mathrm{Ca}^{2+}$ from intracellular stores (Kumar and Foster, 2004; Bodhinathan et al., 2010b). The results suggest that the disruption of feedback loops involving redox state, excitatory/inhibitory neural activity, and activity-induced transcription may contribute to the development of brain aging.

\section{References}

Aizenman E, Hartnett KA, Reynolds IJ (1990) Oxygen free radicals regulate NMDA receptor function via a redox modulatory site. Neuron 5:841846. CrossRef Medline

Ando S, Ohashi Y (1991) Longitudinal study on age-related changes of working and reference memory in the rat. Neurosci Lett 128:17-20. CrossRef Medline

Bannerman DM, Niewoehner B, Lyon L, Romberg C, Schmitt WB, Taylor A, Sanderson DJ, Cottam J, Sprengel R, Seeburg PH, Köhr G, Rawlins JN (2008) NMDA receptor subunit NR2A is required for rapidly acquired spatial working memory but not incremental spatial reference memory. J Neurosci 28:3623-3630. CrossRef Medline

Barnes CA, Rao G, Foster TC, McNaughton BL (1992) Region-specific age effects on AMPA sensitivity: electrophysiological evidence for loss of synaptic contacts in hippocampal field CA1. Hippocampus 2:457-468. CrossRef Medline

Barnes CA, Rao G, Shen J (1997) Age-related decrease in the N-methyl-DaspartateR-mediated excitatory postsynaptic potential in hippocampal region CA1. Neurobiol Aging 18:445-452. CrossRef Medline

Bernard CL, Hirsch JC, Khazipov R, Ben-Ari Y, Gozlan H (1997) Redox modulation of synaptic responses and plasticity in rat CA1 hippocampal neurons. Exp Brain Res 113:343-352. CrossRef Medline

Billard JM, Rouaud E (2007) Deficit of NMDA receptor activation in CA1 hippocampal area of aged rats is rescued by D-cycloserine. Eur J Neurosci 25:2260-2268. CrossRef Medline

Bodhinathan K, Kumar A, Foster TC (2010a) Intracellular redox state alters NMDA receptor response during aging through $\mathrm{Ca}^{2+} /$ calmodulindependent protein kinase II. J Neurosci 30:1914-1924. CrossRef Medline

Bodhinathan K, Kumar A, Foster TC (2010b) Redox sensitive calcium stores underlie enhanced after hyperpolarization of aged neurons: role for ryanodine receptor mediated calcium signaling. J Neurophysiol 104: 2586-2593. CrossRef Medline 
Boric K, Muñoz P, Gallagher M, Kirkwood A (2008) Potential adaptive function for altered long-term potentiation mechanisms in aging hippocampus. J Neurosci 28:8034-8039. CrossRef Medline

Brim BL, Haskell R, Awedikian R, Ellinwood NM, Jin L, Kumar A, Foster TC, Magnusson KR (2013) Memory in aged mice is rescued by enhanced expression of the GluN2B subunit of the NMDA receptor. Behav Brain Res 238:211-226. CrossRef Medline

Burgdorf J, Zhang XL, Weiss C, Matthews E, Disterhoft JF, Stanton PK, Moskal JR (2011) The N-methyl-d-aspartate receptor modulator GLYX-13 enhances learning and memory, in young adult and learning impaired aging rats. Neurobiol Aging 32:698-706. CrossRef Medline

Deupree DL, Bradley J, Turner DA (1993) Age-related alterations in potentiation in the CA1 region in F344 rats. Neurobiol Aging 14:249-258. CrossRef Medline

Foster TC (2012) Dissecting age-related cognitive decline in rodent models: $\mathrm{N}$-methyl-D-aspartate receptors and voltage-dependent Ca2 + channels in senescent synaptic plasticity. Prog Neurobiol 96:283-303. CrossRef Medline

Foster TC, Norris CM (1997) Age-associated changes in Ca(2+)-dependent processes: relation to hippocampal synaptic plasticity. Hippocampus 7:602-612. CrossRef Medline

Foster TC, Defazio RA, Bizon JL (2012) Characterizing cognitive aging of spatial and contextual memory in animal models. Front Aging Neurosci 4:12. CrossRef Medline

Fouquet C, Petit GH, Auffret A, Gaillard E, Rovira C, Mariani J, Rondi-Reig L (2011) Early detection of age-related memory deficits in individual mice. Neurobiol Aging 32:1881-1895. CrossRef Medline

Ghosh D, LeVault KR, Barnett AJ, Brewer GJ (2012) A reversible early oxidized redox state that precedes macromolecular ROS damage in aging nontransgenic and 3xTg-AD mouse neurons. J Neurosci 32:5821-5832. CrossRef Medline

Gozlan H, Khazipov R, Diabira D, Ben-Ari Y (1995) In CA1 hippocampal neurons, the redox state of NMDA receptors determines LTP expressed by NMDA but not by AMPA receptors. J Neurophysiol 73:2612-2617. Medline

Hardingham GE, Fukunaga Y, Bading H (2002) Extrasynaptic NMDARs oppose synaptic NMDARs by triggering CREB shut-off and cell death pathways. Nat Neurosci 5:405-414. CrossRef Medline

Haxaire C, Turpin FR, Potier B, Kervern M, Sinet PM, Barbanel G, Mothet JP, Dutar P, Billard JM (2012) Reversal of age-related oxidative stress prevents hippocampal synaptic plasticity deficits by protecting D-serinedependent NMDA receptor activation. Aging Cell 11:336-344. CrossRef Medline

Hsu KS, Huang CC, Liang YC, Wu HM, Chen YL, Lo SW, Ho WC (2002) Alterations in the balance of protein kinase and phosphatase activities and age-related impairments of synaptic transmission and long-term potentiation. Hippocampus 12:787-802. CrossRef Medline

Jucker M, Oettinger R, Bättig K (1988) Age-related changes in working and reference memory performance and locomotor activity in the Wistar rat. Behav Neural Biol 50:24-36. CrossRef Medline

Kumar A, Foster TC (2004) Enhanced long-term potentiation during aging is masked by processes involving intracellular calcium stores. J Neurophysiol 91:2437-2444. CrossRef Medline

Kumar A, Rani A, Tchigranova O, Lee WH, Foster TC (2012) Influence of late-life exposure to environmental enrichment or exercise on hippocampal function and CA1 senescent physiology. Neurobiol Aging 33: 828.e821-e817. CrossRef Medline

Landfield PW, Pitler TA, Applegate MD (1986) The effects of high Mg2+to-Ca2 + ratios on frequency potentiation in hippocampal slices of young and aged rats. J Neurophysiol 56:797-811. Medline
Lee WH, Kumar A, Rani A, Herrera J, Xu J, Someya S, Foster TC (2012) Influence of viral vector-mediated delivery of superoxide dismutase and catalase to the hippocampus on spatial learning and memory during aging. Antioxid Redox Signal 16:339-350. CrossRef Medline

Matthews EA, Linardakis JM, Disterhoft JF (2009) The fast and slow afterhyperpolarizations are differentially modulated in hippocampal neurons by aging and learning. J Neurosci 29:4750-4755. CrossRef Medline

McDonald RJ, Hong NS, Craig LA, Holahan MR, Louis M, Muller RU (2005) NMDA-receptor blockade by CPP impairs post-training consolidation of a rapidly acquired spatial representation in rat hippocampus. Eur J Neurosci 22:1201-1213. CrossRef Medline

Nakazawa K, Sun LD, Quirk MC, Rondi-Reig L, Wilson MA, Tonegawa S (2003) Hippocampal CA3 NMDA receptors are crucial for memory acquisition of one-time experience. Neuron 38:305-315. CrossRef Medline

Norris CM, Halpain S, Foster TC (1998) Alterations in the balance of protein kinase/phosphatase activities parallel reduced synaptic strength during aging. J Neurophysiol 80:1567-1570. Medline

Papadia S, Soriano FX, Léveillé F, Martel MA, Dakin KA, Hansen HH, Kaindl A, Sifringer M, Fowler J, Stefovska V, McKenzie G, Craigon M, Corriveau R, Ghazal P, Horsburgh K, Yankner BA, Wyllie DJ, Ikonomidou C, Hardingham GE (2008) Synaptic NMDA receptor activity boosts intrinsic antioxidant defenses. Nat Neurosci 11:476-487. CrossRef Medline

Rex CS, Kramár EA, Colgin LL, Lin B, Gall CM, Lynch G (2005) Long-term potentiation is impaired in middle-aged rats: regional specificity and reversal by adenosine receptor antagonists. J Neurosci 25:5956-5966. CrossRef Medline

Robillard JM, Gordon GR, Choi HB, Christie BR, MacVicar BA (2011) Glutathione restores the mechanism of synaptic plasticity in aged mice to that of the adult. PLoS One 6:e20676. CrossRef Medline

Speisman RB, Kumar A, Rani A, Pastoriza JM, Severance JE, Foster TC, Ormerod BK (2013) Environmental enrichment restores neurogenesis and rapid acquisition in aged rats. Neurobiol Aging 34:263-274. CrossRef Medline

Steele RJ, Morris RG (1999) Delay-dependent impairment of a matchingto-place task with chronic and intrahippocampal infusion of the NMDAantagonist D-AP5. Hippocampus 9:118-136. CrossRef Medline

Tang LH, Aizenman E (1993) The modulation of N-methyl-D-aspartate receptors by redox and alkylating reagents in rat cortical neurones in vitro. J Physiol 465:303-323. Medline

Tombaugh GC, Rowe WB, Chow AR, Michael TH, Rose GM (2002) Thetafrequency synaptic potentiation in CA1 in vitro distinguishes cognitively impaired from unimpaired aged Fischer 344 rats. J Neurosci 22:99329940. Medline

Tombaugh GC, Rowe WB, Rose GM (2005) The slow afterhyperpolarization in hippocampal CA1 neurons covaries with spatial learning ability in aged Fisher 344 rats. J Neurosci 25:2609-2616. CrossRef Medline

von Engelhardt J, Doganci B, Jensen V, Hvalby Ø, Göngrich C, Taylor A, Barkus C, Sanderson DJ, Rawlins JN, Seeburg PH, Bannerman DM, Monyer H (2008) Contribution of hippocampal and extra-hippocampal NR2Bcontaining NMDA receptors to performance on spatial learning tasks. Neuron 60:846-860. CrossRef Medline

Zhang JR, Andrus PK, Hall ED (1993) Age-related regional changes in hydroxyl radical stress and antioxidants in gerbil brain. J Neurochem 61: 1640-1647. CrossRef Medline

Zhang SJ, Buchthal B, Lau D, Hayer S, Dick O, Schwaninger M, Veltkamp R, Zou M, Weiss U, Bading H (2011) A signaling cascade of nuclear calcium-CREB-ATF3 activated by synaptic NMDA receptors defines a gene repression module that protects against extrasynaptic NMDA receptor-induced neuronal cell death and ischemic brain damage. J Neurosci 31:4978-4990. CrossRef Medline 